\title{
Greenhouse Gas Mitigation in Forest and Agricultural Lands: Reducing Emissions ${ }^{1}$
}

\author{
Solomon G. Haile, Clyde W. Fraisse, P.K. Ramachandran Nair and Vimala D. Nair²
}

\section{Greenhouse gases}

'Greenhouse gas' (GHG) refers to gases in the atmosphere that are of both natural and synthetic origin. Natural gases include water vapor, carbon dioxide $\left(\mathrm{CO}_{2}\right)$, carbon monoxide $(\mathrm{CO})$, methane $\left(\mathrm{CH}_{4}\right)$, nitrous oxide $\left(\mathrm{N}_{2} \mathrm{O}\right)$, nitrogen oxide $(\mathrm{NO})$, nitrogen dioxide $\left(\mathrm{NO}_{2}\right)$ and ozone $\left(\mathrm{O}_{3}\right)$. Compounds of hydrofluorocarbons (HFCs), perfluorocarbons (PFCs), and sulfur hexafluoride (SF6) are gases that possess similar attributes but they are a result of human activities such as industrial processes. The most abundant of all the greenhouse gases is water vapor.

\section{Greenhouse effect and global warming}

Earth's climate is governed by a number of factors but the main driving force is the energy from the sun and what happens with it as it hits the Earth. It can be absorbed or reflected by Earth's atmosphere and surface and also re-radiated back to space in the form of infrared radiation. A portion of the infrared energy radiated back to space is absorbed by heat-trapping GHGs in the atmosphere that create an insulating layer and control the Earth's temperature. This creates a natural "greenhouse effect". Strictly speaking the term greenhouse effect does not describe well the effect of GHGs in the atmosphere since the main mechanism operating in a greenhouse is not the trapping of infrared radiation but the restriction of the flow of warmed air to the outside of the greenhouse. Thanks to the GHGs, the Earth's average surface temperature is around 60F, which is hospitable to most forms of life. Without this delicate balance provided by GHGs, Earth's temperatures would be much lower than they are now, and life as known today would not be possible. However, increasing concentrations of GHGs caused by human activities leads to an increase in the Earth's temperature. This phenomenon, popularly called "global warming", is a matter of serious concern.

Since the onset of the Industrial Revolution humans have been causing the emission of more and more GHGs into the atmosphere. It is widely believed that these human activities are contributing to global warming by adding large amounts of heat-trapping GHGs to the atmosphere. A major reason for the

1. This document is AE443, one of a series of the Agricultural and Biological Engineering Department, Florida Cooperative Extension Service, Institute of Food and Agricultural Sciences, University of Florida. Original publication date December 2008. Visit the EDIS Web Site at http://edis.ifas.ufl.edu.

2. Solomon G. Haile, postdoctoral research associate, Soil and Water Science Department; Clyde W. Fraisse, assistant professor, Agricultural and Biological Engineering Department; P.K. Ramachandran Nair, professor, School of Forest Resources and Conservation; and Vimala D. Nair, research associate professor, Soil and Water Science Department; Florida Cooperative Extension Service, Institute of Food and Agricultural Sciences, University of Florida, Gainesville, FL 32611.

The Institute of Food and Agricultural Sciences (IFAS) is an Equal Opportunity Institution authorized to provide research, educational information and other services only to individuals and institutions that function with non-discrimination with respect to race, creed, color, religion, age, disability, sex, sexual orientation, marital status, national origin, political opinions or affiliations. U.S. Department of Agriculture, Cooperative Extension Service, University of Florida, IFAS, Florida A. \& M. University Cooperative Extension Program, and Boards of County Commissioners Cooperating. Larry Arrington, Dean 
GHG build-up is the increase in combustion of fossil fuels. For example, electricity generation from coal-fired power plants and the combustion of oil or natural gas for heat result in the release of $\mathrm{CO}_{2}$ and other heat-trapping gases into the atmosphere. Land-use changes, such as deforestation and consequent burning of biomass, are another major source of GHGs to the atmosphere.

\section{Relative global warming potential of GHGs}

Various GHGs differ in their potential contribution to global warming. The global warming potential (GWP) compares the relative ability of each GHG to trap heat in the atmosphere over a certain period. According to Intergovernmental Panel on Climate Change (IPCC, 1996) guidelines, $\mathrm{CO}_{2}$ is the reference gas with a GWP of 1 . Based on a period of 100 years, the GWP of methane is 21 , implying that a ton of methane is 21 times more effective in trapping heat than a ton of $\mathrm{CO}_{2}$. The GWP for $\mathrm{N}_{2} \mathrm{O}$ is 310 .

Carbon dioxide equivalent $\left(\mathrm{CO}_{2}-\mathrm{Eq}\right)$ is a measure that expresses, for a given mixture and amount of greenhouse gas, the amount of $\mathrm{CO}_{2}$ that would have the same GWP. Carbon dioxide equivalent is measured over a specified timescale (generally 100 years), and therefore it represents a value that is integrated over a period of time rather than a measure at a specified time.

\section{Current trends of major GHGs emissions}

Greenhouse gas concentrations in the atmosphere have generally increased since the industrial era. Emission of three major GHGs $\mathrm{CO}_{2}$, $\mathrm{CH}_{4}$, and $\mathrm{N}_{2} \mathrm{O}$ increased by $70 \%$ during $1970-2004$ and by $24 \%$ during 1990 - 2004 (Barker et al., 2007), at varying rates among different GHGs. Atmospheric $\mathrm{CO}_{2}$ concentration increased by approximately 100 parts per million (ppm) from its pre-industrial level of $280 \mathrm{ppm}$ in 1870 s to $379 \mathrm{ppm}$ in 2005. The annual mean growth rate of atmospheric $\mathrm{CO}_{2}$ concentration during 2000 - 2005 period was higher than that of the 1990s (IPCC, 2007).
Methane emission has increased by $40 \%$ from 1970 to 2004. While most of this increase is due to a rise in combustion of fossil fuel, the largest source of methane emissions was still agricultural activity. Similarly, $\mathrm{N}_{2} \mathrm{O}$ emissions grew by about $50 \%$, mainly due to an increased use of fertilizer and other agricultural activities. Industrial $\mathrm{N}_{2} \mathrm{O}$ emissions, however, have decreased during the same period (Barker et al., 2007).

\section{GHG emissions from agricultural and forest lands}

Agricultural and forestry activities result mainly in the release of the following GHGs:

- Methane $\left(\mathrm{CH}_{4}\right)$;

- Nitrous oxide $\left(\mathrm{N}_{2} \mathrm{O}\right)$;

- Carbon dioxide $\left(\mathrm{CO}_{2}\right)$.

Methane and $\mathrm{N}_{2} \mathrm{O}$ are the primary GHGs emitted by agricultural activities. Methane emissions from animal enteric fermentation and manure management represented about $30 \%$ of total $\mathrm{CH}_{4}$ emissions in the USA from human (anthropogenic) activities in 2006 (US-EPA, 2008). Rice paddies are also a significant source of $\mathrm{CH}_{4}$ emissions. Soil management activities such as fertilizer application and other cropping practices accounted for $72 \%$ of the total US $\mathrm{N}_{2} \mathrm{O}$ emissions in 2006. Although $\mathrm{CO}_{2}$ emissions from agriculture are relatively small when compared to $\mathrm{CH}_{4}$ and $\mathrm{N}_{2} \mathrm{O}$ emissions, the activities that mostly contribute to its release are (FAO, 2000):

- Use of fossil fuels in farm operations;

- Use of inputs that are energy-intensive to manufacture (particularly fertilizers);

- Cultivation of soils resulting in the loss of soil organic matter.

In 2004, land-use change and forestry contributed $19 \%$ and agriculture $17 \%$ of the total world GHG emissions (US-EPA, 2005). Soil degradation aggravates gaseous emissions from terrestrial ecosystems. Emission of $\mathrm{CO}_{2}$ and other GHGs by soil degradation is significant. The relatively stable state of the soil organic carbon 
(SOC) pool in undisturbed ecosystems is drastically disturbed by human activities such as conversion of natural to agricultural ecosystems. These activities often lead to a reduction in the amount of root and litter biomass returned to the soil. The SOC pool is diminished by an increase in the oxidation rate and losses due to erosion and leaching. Ploughing, drainage and other drastic disturbances increase the magnitude of SOC loss. Lal (2003) estimated that one-half to two-thirds of the SOC pool might be lost within 5 years in the tropics and 50 years in temperate regions, and after losing 20-50 Mg [1 megagram $(\mathrm{Mg})=10^{6}$ gram $\mathrm{C} / \mathrm{ha}$ a new equilibrium may be attained.

Several estimates of the historic loss of SOC pool at global scale due to land use change are available (Bohn, 1978; Buringh, 1984; Wallace, 1994; Houghton, 1995; IPCC, 1995; Schimel, 1995). They range from 40 to $537 \mathrm{Pg}[1$ petagram $(\mathrm{Pg})=$ $10^{15}$ grams $=1$ billion metric tons $]$. The corresponding value for US soils is $5 \mathrm{Pg}$ (Lal, 1999). Rozanov et al. (1993) observed that world soils had lost the stable, long lasting remnant of decaying organic material or humus $(58 \% \mathrm{C})$ at a rate of $25 \mathrm{Tg}$

$\left[1\right.$ teragram $(\mathrm{Tg})=10^{12}$ grams $=1$ million metric tons] annually ever since agriculture began 10,000 years ago, 300 million tons per year in the past 300 years and 760 million tons per year in the past 50 years.

They estimated that nearly $16 \%$ of the original SOC pool might have been lost.

Overall trends in GHG emissions in agriculture are responsive to global changes: increases in GHG emissions are expected as diets change and demand for food increases with population growth. Increasing global warming may eventually release more soil carbon. Although agriculture is currently a substantial source of GHGs, it has also great potential to reduce the buildup of these gases in the atmosphere. Some relatively low-cost agricultural practices can reduce emissions or remove $\mathrm{CO}_{2}$ from the atmosphere. For instance, the use of agricultural residues for energy does not require changes in land use, and residues are a relatively low-cost feedstock.
Emerging technologies may permit reductions in emissions per unit of food produced. On the other hand, absolute emissions are likely to grow. Thus, widespread concerns about global climate change have led to agreements to reduce emissions of GHG and, under certain circumstances, to count additional carbon absorbed in soils and vegetation as part of emission reductions.

\section{Reducing agricultural and forest GHG emissions}

\section{A. Reducing agricultural GHG emissions}

Compared with other sectors, relatively little work has been done on how to reduce emissions from agricultural crop land and animal production systems. Emission of GHG in agricultural practices could be reduced in several ways. These can be summarized as 1) activities that are directed toward reducing emissions, 2) enhancing sinks, and 3) offsetting emissions. Many agricultural land management practices have great potential for reducing GHG emissions. Agricultural land management practices with focus on nutrient management, animal production system, and vegetation targeting reduction of GHG emissions via appropriate management practices are listed in Table 1.

Several ways of reducing non- $\mathrm{CO}_{2}$ emission are available. Nitrous oxide emissions from fertilizers could be reduced by making more efficient use of fertilizers. Mitigation options for soil $\mathrm{CH}_{4}$ production primarily relate to enhancing soil oxygen diffusion through water management, land use change, minimized compaction and soil fertility management. Methane emissions from rice can be cut by periodically draining the soil to aerate roots which in turn reduces the levels of decomposition occurring in anaerobic conditions. Methane emissions from livestock could be cut using nutritional supplements, preventing overgrazing, and adopting different feeding patterns (such as smaller but more frequent feeding). Research into different livestock breeds can also be considered a long term solution. Methane emissions from manure could be cut by switching to waste management practices that favor aerobic decomposition. Although the process will also increase $\mathrm{CO}_{2}$ emission, the global warming potential 
(GWP) of $\mathrm{CH}_{4}$ is 25 fold greater than $\mathrm{CO}_{2}$. Alternatively, capturing methane emissions by storing wastes in an anaerobic environment can be a particularly attractive way considering that the methane (biogas) can be used as an energy source. For instance, installing manure digesters on livestock operations will reduce the amount of methane emissions from livestock manure. Energy from the manure digesters could be used to generate heat or power, which offsets fossil fuel-based energy production and the associated GHG emissions. Avoiding crop-residue burning would also reduce methane and nitrous oxide emissions.

Modifying the agricultural land management operations such as crop tilling could also be an important strategy for $\mathrm{CO}_{2}$ emission savings (Table 2 ). The IPCC projects that savings here could amount to 1 to $2 \mathrm{Pg}$ of $\mathrm{CO}_{2}$ reductions in 2020 at up to $\$ 27 /$ metric ton of $\mathrm{CO}_{2}$. The contribution of agriculture to climate change can also be reduced by tackling its indirect effect on emissions from the power, industrial and transportation sectors. For example, more efficient machinery and more efficient use of fertilizer will reduce upstream emissions from the utilities and industrial sectors.

\section{B. Reducing GHG emissions in forestry}

Greenhouse gas emissions in the forestry sector can be reduced and avoided by two approaches: 1) reduce direct emissions, and 2) produce bioenergy (renewable energy produced from organic matter) to replace emission-intensive products. Atmospheric $\mathrm{CO}_{2}$ can be sequestered in tree biomass and soil, which can act as carbon sinks. Carbon stored in tree biomass and soil can be protected and preserved to avoid eventual releases of $\mathrm{CO}_{2}$ to the atmosphere. Emissions of $\mathrm{CO}_{2}$ could also be avoided by reducing the use of emission-intensive inputs and/or by replacing fossil fuel with bioenergy produced in forestry and agricultural production systems.

Under current conditions, US agricultural soils and forests sequester about $800 \mathrm{Tg}$ of $\mathrm{CO}_{2}-\mathrm{Eq}$ per year (US-EPA, 2005), over $90 \%$ of which is from forest carbon sequestration. This amount alone offsets about $10 \%$ of national GHG emissions. The ultimate goal is, however, to take various actions that enhance sequestration above this level as well as to reduce $\mathrm{CO}_{2}$ emission. Opportunities for reducing GHG emissions in forestry include improved forest management (e.g., altering harvest schedules or management inputs), forest preservation, and use of biofuel substitutes. Consideration should also be given to management practices that store carbon and reduce greenhouse gases when setting priorities and implementing forest conservation programs (Table 3).

\section{Conclusion}

Land management practices discussed above have the potential to reduce GHG emissions in the agricultural and forestry sectors of Florida. To this end, it is very important to develop best management practices that reduce GHG emission and integrate those practices into agricultural and forest lands in cost-effective ways. The carbon market is currently at its early stage but it is growing fast. The opportunity for trading carbon saved is believed to create a financial benefit to land owners. An incentive, such as, is expected to increase the adoption of land management practices which focus on GHG emission-reducing. Overall, this can lead to an increased contribution of agricultural and forest sectors to the mitigation of climate change impacts.

\section{References}

Barker, T., I. Bashmakov, L. Bernstein, J. E. Bogner, P. R. Bosch, R. Dave, O. R. Davidson, B. S. Fisher, S. Gupta, K. Halsnæs, G.J. Heij, S. Kahn Ribeiro, S. Kobayashi, M. D. Levine, D. L. Martino, O. Masera, B. Metz, L. A. Meyer, G.-J. Nabuurs, A. Najam, N. Nakicenovic, H. -H. Rogner, J. Roy, J. Sathaye, R. Schock, P. Shukla, R. E. H. Sims, P. Smith, D. A. Tirpak, D. Urge-Vorsatz, D. Zhou. 2007. Technical Summary. In: B. Metz, O. R. Davidson, P. R. Bosch, R. Dave, L. A. Meyer (Eds). Climate Change 2007: Mitigation. Contribution of Working Group III to the Fourth Assessment Report of the IPCC, Cambridge University Press, Cambridge, UK and New York, NY, USA.

Birdsey, R.A. 1996. Regional estimates of timber volume and forest carbon for fully stocked timberland, average management after final clearcut harvest. In: R.N. Sampson, D. Hair Forests Global Change: Volume 2, Forest Management Opportunities for Mitigating Carbon Emissions, American Forests, Washington, DC, USA. 
Bohn, H. 1978. On organic soil C and CO2. Tellus 30: 472-475.

Buringh, P. 1984. Organic carbon in soils of the world. pp. 41-109. In: G.M Woodwell (Ed). The role of terrestrial vegetation in the global carbon cycle. SCOPE vol. 23, Wiley, Chichester, UK.

FAO. 2000. Carbon sequestration options under the clean development mechanism to address land degradation. World Soil Resources Reports 92. FAO and IFAD, Rome, Italy.

Houghton, R.A. 1995. Changes in the storage of industrial carbon since 1850. pp. 45-65. In: Lal, R., Kimble, J.M., Levine, E. and Stewart, B.A., Editors, 1995. Soils and global change, CRC/Lewis, Boca Raton.

Intergovernmental Panel on Climate Change (IPCC). 2007. Climate change 2007: The physical science basis. Contribution of working group I to the fourth assessment report of the IPCC. S. Solomon, D. Qin, M. Manning, Z. Chen, M. Marquis, K.B. Averyt, M. Tignor, H.L. Miller (Eds). Cambridge University Press, Cambridge, United Kingdom, and New York, NY, USA.

IPCC. 1995. Climate change 1995. Working group 1. IPCC. Cambridge Univ. Press, Cambridge, UK.

IPCC. 1996. Climate Change 1995: The Science of Climate Change. J. T. Houghton, L. G. Meira Filho, B. A. Callander, N. Harris, A. Kattenberg, and K. Maskell (Eds). Cambridge University Press, Cambridge, UK.

IPCC. 2000. Special report on land use, land-use change, and forestry. R.T. Watson et al. (eds.), Intergovernmental Panel on Climate Change, Cambridge University Press, p. 184.

Lal, R. 1999. Soil management and restoration for $\mathrm{C}$ sequestration to mitigate the accelerated greenhouse effect. Prog. Environ. Sci. 1:07-326.

Lal, R. 2003. Soil Erosion and the Global Carbon Budget. Environment International (29)4:

437-450.
Lal, R., J. M. Kimble, R. F. Follett, and C.V. Cole. 1999. The potential of US cropland to sequester carbon, and mitigate the greenhouse effect. CRC Press LLC. Lewis publishers

Mulkey, S., J. Alavalapati, A. Hodges, A. C. Wilkie, and S. Grunwald. 2008. Opportunities for Greenhouse Gas Reduction through Forestry and Agriculture in Florida. Report. School of Natural Resources and Environment. University of Florida.

Row, C. 1996. Effects of selected forest management options on carbon storage. pp. 59-90. In: R.N. Sampson, D. Hair Forests Global Change: Volume 2, Forest Management Opportunities for Mitigating Carbon Emissions, American Forests, Washington, DC, USA.

Rozanov, B.G., V. Targulian, and D.S. Orlov. 1993. Soils. pp. 203-214. In: B.L Turner II, W.C. Clark, R.W. Kates, J.F. Richards, J.T. Mathews, and W. B. Meyer, (Eds). The earth as transformed by humans action: global and regional changes in the biosphere over the past 300 years, Cambridge Univ. Press, Cambridge, UK.

Schimel, D.S. 1995. Terrestrial ecosystems and the carbon cycle. Global Change Biol. 1:77-91.

United States Environmental Protection Agency (US-EPA). 2005. Greenhouse gas mitigation potential in US agriculture and forestry. EPA 430-R-05-006.

US-EPA. 2008. Inventory of US Greenhouse Gas Emissions and Sinks: 1990-2006. EPA 430-R-08-005.

Wallace, A. 1994. Soil organic matter must be restored to near original levels. Commun. Soil Sci. Plant Anal. 25:29-35. 
Table 1. Land-use management practices that can be used as strategies to reduce green house gas (GHG) emissions.

\begin{tabular}{|c|c|c|c|c|c|}
\hline \multirow{2}{*}{ Category } & \multicolumn{2}{|c|}{ Management Practice } & \multicolumn{3}{|c|}{ GHGs affected } \\
\hline & Activity & Description & $\mathrm{CO}_{2}$ & $\mathrm{CH}_{4}$ & $\mathrm{~N}_{2} \mathrm{O}$ \\
\hline Nutrients & Nutrient management planning & $\begin{array}{l}\text { Timing, rate and type of } \\
\text { fertilizer applications, }\end{array}$ & $x^{2}$ & $x^{4}$ & $x^{2}$ \\
\hline & Fertilizer land application option & $\begin{array}{l}\text { Incorporating manure } \\
\text { fertilizer, synchronizing N } \\
\text { supply with plant need } \\
\text { through timing and } \\
\text { placement }\end{array}$ & & $x$ & $x$ \\
\hline & $\begin{array}{l}\text { Proper nutrient crediting } \\
\text { (manure/crops) }\end{array}$ & $\begin{array}{l}\text { Crediting nutrient inputs from } \\
\text { prior year amendments or } \\
\text { legumes }\end{array}$ & & $x$ & $x$ \\
\hline & Residue management & $\begin{array}{l}\text { Using reduced or no-till } \\
\text { practices reduces }\end{array}$ & $\mathrm{x}$ & & $x$ \\
\hline & Pasture and hay planting & $\begin{array}{l}\text { Planting high nutrient species } \\
\text { and maintaining permanent, } \\
\text { vigorous plant growth }\end{array}$ & $x$ & $x$ & $x$ \\
\hline & Managed grazing & $\begin{array}{l}\text { Planting high nutrient species } \\
\text { and maintaining vigorous } \\
\text { plant growth }\end{array}$ & $x$ & $x$ & $x$ \\
\hline \multirow[t]{5}{*}{ Animal } & Manure brokerage & $\begin{array}{l}\text { Relocating manure fertilizer } \\
\text { from crop land with excesses } \\
\text { to crop land with nutrient } \\
\text { deficiencies manure } \\
\text { nutrients }\end{array}$ & & $x$ & $x$ \\
\hline & Dietary management & $\begin{array}{l}\text { Managing animal diets } \\
\text { effectively }\end{array}$ & & $x$ & $x$ \\
\hline & Manure storage & $\begin{array}{l}\text { Storing manure in lagoon } \\
\text { systems, and with capping or } \\
\text { digestion technology, }\end{array}$ & & $x$ & $x$ \\
\hline & Manure digestion & Manure digestion technology & & $x$ & $x$ \\
\hline & Conservation crop rotation & $\begin{array}{l}\text { Using legume crops in } \\
\text { rotation }\end{array}$ & $x$ & & \\
\hline \multirow[t]{5}{*}{ Cover } & Cover crop & Using cover crops & $\mathrm{x}$ & & $\mathrm{x}$ \\
\hline & Filter strip & $\begin{array}{l}\text { Maintaining groundcover in } \\
\text { filter strips }\end{array}$ & $x$ & & $\mathrm{x}$ \\
\hline & Grassed waterway & $\begin{array}{l}\text { Maintaining groundcover in } \\
\text { grassed waterways }\end{array}$ & $x$ & & $\mathrm{x}$ \\
\hline & Tree/shrub Establishment & $\begin{array}{l}\text { Planting trees and shrubs in } \\
\text { windrows, shelterbelts, } \\
\text { riparian, and conservation } \\
\text { areas }\end{array}$ & $\mathrm{x}$ & & $\mathrm{x}$ \\
\hline & Wetland Creation/restoration & $\begin{array}{l}\text { Creating or restoring } \\
\text { wetlands }\end{array}$ & $\mathrm{x}$ & $x$ & $x$ \\
\hline
\end{tabular}


Table 2. Representative management practices that avoid $\mathrm{CO}_{2}$ emission and their carbon sequestration rates and saturation periods 1 for key agriculture, and land-use change

\begin{tabular}{|c|c|c|c|}
\hline Activity & $\begin{array}{l}\text { C Sequestration Rate in US } \\
\text { (metric tons of } \mathrm{CO}_{2} \mathrm{acre}^{-1} \mathrm{yr}^{-1} \text { ) }\end{array}$ & Time period ${ }^{1}$ & References \\
\hline $\begin{array}{l}\text { Reduced tillage in } \\
\text { crop lands }\end{array}$ & $0.6-1.1$ & $15-20 y r$ & $\begin{array}{l}\text { West and Post } \\
(2002)\end{array}$ \\
\hline $\begin{array}{l}\text { Changes in grazing } \\
\text { management }\end{array}$ & $0.07-1.9$ & $25-50 y r$ & Lal et al. (1999) \\
\hline $\begin{array}{l}\text { Biofuel }^{2} \text { substitute for } \\
\text { fossil fuels }\end{array}$ & $4.8-5.5$ & & Lal et al. (1999) \\
\hline \multicolumn{4}{|c|}{$\begin{array}{l}\text { Notes: } \\
1 \text { Time over which sequestration may occur before saturating assuming no disturbance, harvest or interruption of } \\
\text { practice } \\
2 \text { Solid, liquid, or gas fuel derived from recently dead biological material. }\end{array}$} \\
\hline
\end{tabular}

Table 3. Forestry practices that reduce or avoid carbon dioxide $\left(\mathrm{CO}_{2}\right)$ emission by preserving and enchaining carbon sequestration. Source: US-EPA 2005.

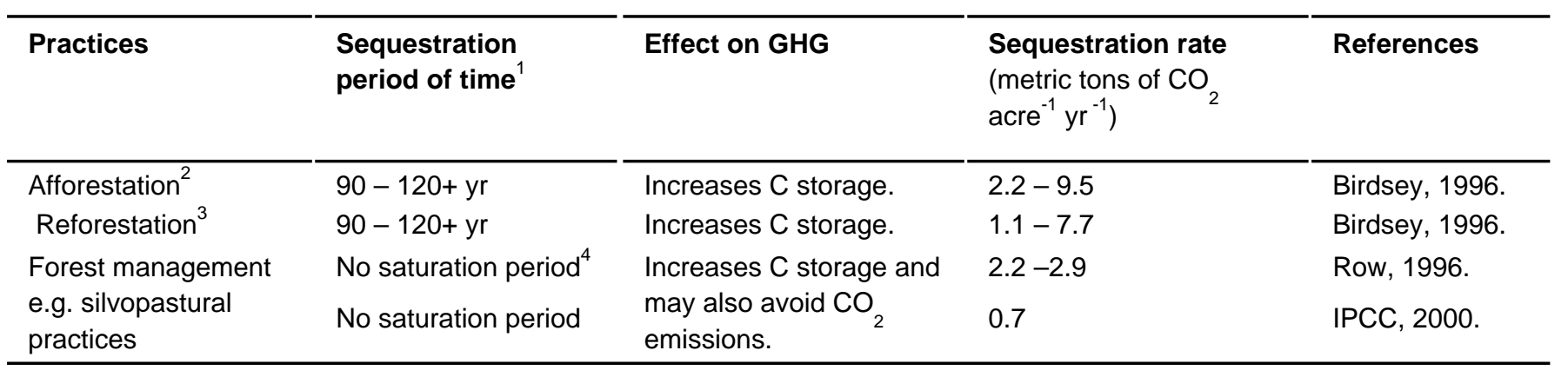

Notes:

1. Time over which sequestration may occur before saturating (assuming no disturbance, harvest or interruption of practice).

2. The term afforestation refers to establishing a forest on land that is not a forest.

3. The term reforestation refers to the reestablishment of the forest after its removal, or planting more trees.

4. If wood products included in accounting, saturation does not necessarily occur if $\mathrm{C}$ continuously flows into products. 